||||||||||||||||||||||||||||

論 文

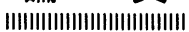

\title{
アクリル繊維の乾熱二次延伸による 構造変化之熱収縮挙動
}

\author{
京都工芸繊維大学工芸学部 甫 天 正 靖（会員） \\ 京都工芸織維大学工芸学部 伊 藤 泰 輔 \\ 神戸海星女子学院大学文学部関白哲 生（会員） \\ 日本エクスラン工業(株)西大寺工場＼cjkstart荒＼cjkstart井＼cjkstart康二郎
}

\section{Structural Changes and Thermo-Shrinking Properties in Secondarily Dry Heat- Stretched Acrylic Fibers}

\author{
Masanobu Hoten*, Taisuke Ito*, Tetsuo Sekiguchi**, Kojiro Arai*** \\ *Faculty of Engineering and Design, Kyoto Institute of Technology, Matsugasaki, Sakyo-ku, Kyoto \\ ${ }^{* *}$ Faculty of Literature, Kobe Kaisei College, Aotani-cho, Nada-ku, Kobe \\ ***Saidaiji Plant, Japan Exlan Ind. Ltd., Kanaoka-higashi, Okayama
}

\begin{abstract}
Acrylonitrile (AN)/methylacrylate (MA) copolymer having AN/MA ratio of $90 / 10$ by weight was wet-spun and drawn 12 times in hot water. The original sample was then subjected to the steam treatment at various temperatures under unconstrained length. This sample is called with symbol SH. SH was then drawn in dry state under various temperatures and stretch-ratios (named with the symbol ST). The practically important thermoelastic behavior of these acrylic fibers above the glass transition temperatures was studied from shrinkage, stress -strain curve and dye diffusion measurement. An inherent stretch ratio named rubbery elongation limit (REL) is defined to each of SH by the initial straight line part of the stress-strain curve obtained in hot water. ST obtained by drawing SH within REL, were found almost completely recoverable to the original length when subjected to hot water shrinkage treatment. For these fibers, the diffusion coefficient, $D$, of basic dye (C. I. Basic Red 18) showed no appreciable change by stretching. When SH was drawn above REL, the unrecoverable fraction of the length in the hot water shrinkage treatment of ST gradually increased and $D$ clearly decreased with increasing stretch ratio. Based on the more detailed analysis of the quantitative thermoelastic data, structural models for the SH and ST were proposed which are applicable characteristically to acrylic fiber.
\end{abstract}

(Received September 26, 1992)

(Accepted for Publication January 11, 1993)

\section{摘}

要

目的 アクリル繊維の牽切・紡績加工の基礎研究として, アクリロニトリル/アクリル酸メチル共重合体を湿式紡糸し, 熱水 中で高延伸した後, 無緊張下で高温湿熱処理して調製した繊維について, さらにガラス転移点以上の温度で乾熱二次延伸して, 延伸倍率と湿熱収縮性および染色性との関係を調べた。

成果 湿熱処理温度の異なる繊維の二次延伸条件（延伸倍率および延伸温度）条件と二次延伸後の繊維の熱水収縮率および染 料拡散係数との関係を明らかにした．収縮率と染色性の变化および S-S 曲線における变形の特徴に対する解釈から，アクリル 繊維の延伸および収縮の変形機構を微細構造に基づいて考察した。 アクリル䋐維の二次延伸では, 繊維製造段階での高温湿熱処 理により形成された無秩序化領域が, 最初に変形されてゴム弾性的な性質を示すと推論した。 また二次延伸条件がこの無秩序化 領域の変形限界を越えるとゴム弾性的な性質が失われ，収縮率および染料拡散係数が著しく低下することを明らかにした。

(平成 4 年 9 月 26 日受付)

(平成 5 年 1 月 11 日審査終了) 


\section{1. 緒 言}

アクリル繊維の乾熱二次延伸はバルキーヤーンを 製造する紡績加工工程として行われてきた。これは アクリル繊維のトウを Turbo stapler や Seydel な どの牽切機により, ガラス転移点より高い温度で延 伸した後, ガラス転移点以下の温度に急冷し, 延伸 長を保った状態で混綿して紡績原系を作り，後に $100^{\circ} \mathrm{C}$ 湿熱で収縮させることによってバルキーャ ーンに仕上げる工程である。この工程はアクリル繊 維のもつ熱弾性的な性質，すなわち，ガラス転移点 を越える温度域においてゴム弾性の特徴である「大 きな変形に耐えて破壊を起こさず，応力を取り除い た後, 元の長さに回復する」という性質に基づくと 考えられる.

一般のアクリル繊維の製造には $85 \mathrm{wt} \%$ 以上のア クリロニトリルを主成分とし, 非晶性高分子形成モ ノマーを共重合成分として含有する共重合体が用い られる。また染色性之物性向上のため，その製造工 程で紡糸延伸後に熱処理が行われている11.この熱 処理は湿式紡糸繊維においては，無緊張高温湿熱処 理が行われている。このとき紡糸延伸工程では繊維 分子鎖が高度に配向され，二トリル基の高い凝集力 によって網目構造が形成されるが, 続く高温の湿熱 処理工程で非晶領域の分子鎖の配向が乱れ，結晶領 域は配向の変化は少ないが緻密な構造に再編成さ れ，いわゆる二相構造化が進行すると考えられ た ${ }^{1,2,3)}$. 本報ではこのようにして得られたアクリル 繊維の二次延伸（再延伸）を取り扱う。すなわち, この二次延伸における変形においでは，上述のごと く湿熱処理によって無秩序化された凝集力の低い部 分がまず変形されることにより変形がゴム弾性的に 進むとの観点に立ち，二次延伸倍率と弛緩熱収縮現 象との関係および二次延伸に伴う染色性の変化など から延伸中の繊維の微細構造の変化を考察する.

乾熱二次延伸によるトウ牽切工程は, 近年合成繊 維紡績のカード工程に代わる合理化工程として意義 が認められ，アクリル繊維のバルキーヤーンの製造 にとどまらず, カード仕掛けの困難な極細デニール 原綿の梳毛紡績の手段として高付加価値系の製造に む適用が拡がりつつある ${ }^{4}$.

工業的な重要性にもかかわらず，アクリル繊維の 乾熱二次延伸に関する報文は少ない年 ${ }^{5 \sim 7)}$ またその製 造工程に依存して各アクリル繊維の乾熱二次延伸に 対する挙動は異なると思われるが, 乾熱二次延伸に
よる物性変化, 染色性の変化に関する報告はほとん ど見られず，本報はこれらに関して有用な新しい知 見を提供するものと考える.

\section{2. 実 験}

\section{1 試 料}

\section{A. 瀻 維}

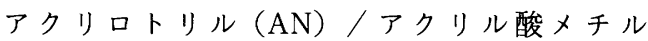
（MA）からなる共重合体（重量組成比 $90 / 10$ 。 ただ し, 仕込みモノマーに繊維における強酸性基導入量 補足のため微少量のメタアリルスルホン酸ソーダを 加えた。強酸性基含有量 $50 \pm 1 \mathrm{mmol} / \mathrm{kg} \cdot$ fiber) を既報の方法 ${ }^{8}$ に従って紡系後, 高倍率に熱延伸 (熱 水中12倍）して得た纎維を原試料とした．次に原試 料を無緊張下, $115^{\circ} \mathrm{C} て ゙ 30 \mathrm{~min}$ 間熱風乾操を行った 試料(以下, US繊維)を, 無緊張下に加圧釜中で 15 $\min$ 間, 飽和水蒸気により, それぞれ, $117,127,132^{\circ} \mathrm{C}$ で湿熱処理を行ったにの湿熱処理後の試料を以下 ではSH繊維と略記し, 必要に応じてカッコ内に湿熱 処理温度を付記する). 湿熱処理後のSH繊維の長さ $L_{\mathrm{SH}}$ を測定し, 原試料(試料長 $L_{\mathrm{OR}}$ )を基準にした熱処 理(熱風乾燥十湿熱処理)時の収縮率を(1)式により求 めた.その值はそれぞれ $24.4 \%\left(117^{\circ} \mathrm{C}\right), 30.1 \%$ $\left(127^{\circ} \mathrm{C}\right), 35.9 \%\left(132^{\circ} \mathrm{C}\right)$ であった. またUS繊維の長 さ $L_{\mathrm{US}}$ を測定して, 原試料長に対する収縮率, $16.5 \%$ を得た. 以上のSH繊維およびUS繊維のいずれもに ついて, 熱収縮後の単繊維の繊度がほぼ $3 \mathrm{~d}$ となるよ うに紡糸時の吐出量を調整した。 また実験には $150 \mathrm{~d}$ /50filのエンドレスの長繊維束を用いた。

$$
\mathrm{SH} \text { 収縮率 }(\%)=\left[\left(L_{\mathrm{OR}}-L_{\mathrm{SH}}\right) / L_{\mathrm{OR}}\right] \times 100
$$

\section{B. 染 料}

カチオン染料 C. I. Basic Red 18 (BR-18) は, 保土谷化学工業㑣)より提供されたコンクケークをエ タノール溶液より再結晶して精製した。

BR-18 は下記の化学構造式で示されるアゾ系の カチオン染料であり ${ }^{9)}$, 塩酸塩の分子量は 426.3 であ る. BR-18 は長時間の熱水処理に対して安定であ り, 後記の平衡染色の条件に耐える.

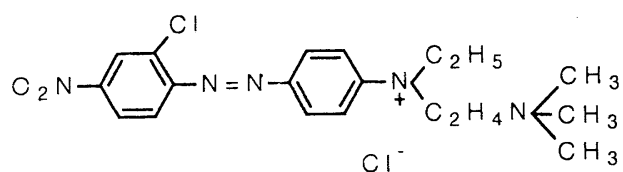

C. I. Basic Red 18 (C. I. 11085) 


\section{2 実験方法}

\section{A. 乾熱二次延伸}

延伸は特別に試作した延伸機を用いて行い，フロ ントローラとバックローラとの回転比を変えること によって延伸比を変化させた. 乾熱延伸は $\mathrm{SH}$ 繊維 束を温度調節された熱板に接触させながら巻取速度 $50 \mathrm{~m} / \mathrm{min}$ で走行させて行った。 乾熱延伸温度は熱 板温度を用いた。本延伸機による延伸は設定した延 伸比と延伸前後で測定した繊度から換算した延伸比 とがよく一致することを確認した。 以下では乾熱二 次延伸繊維を ST 繊維と略記する。

\section{B. 二次延伸䌜維の沸騰水収縮率}

長さ $L_{\mathrm{ST}}$ の ST 繊維を沸騰水中で $15 \mathrm{~min}$ 間無緊 張で弛緩処理し, 室温乾燥後の長さ $L_{\mathrm{SR}}$ を測定して (2)式により，ST 繊維の沸騰水収縮率を求めた。

$\mathrm{ST}$ 収縮率 $(\%)=\left[\left(L_{\mathrm{ST}}-L_{\mathrm{SR}}\right) / L_{\mathrm{ST}}\right] \times 100$

\section{C. 染色速度測定}

常法に従っで, 染色速度曲線を作成した. 染色速 度を表す指数としては，(3)式により $C_{\mathrm{t}} / C_{\infty}$ の $\sqrt{t}$ に対 するプロットの初期勾配から拡散係数 $D$ を計算し て用いた。

$$
C_{t} / C_{\infty}=\left(\frac{4}{\sqrt{\pi}}\right)\left(\frac{D t}{a^{2}}\right)^{1 / 2}
$$

ここで, $C_{\mathrm{t}}$ は時間 $t$ における染着量, $C_{\infty}$ は平衡染 着量, $a$ は円形断面を有する繊維の半径を表す。 $a$ は四塩化炭素/キシレンを用いた密度勾配管法によ り $30^{\circ} \mathrm{C}$ で求めた比重 1.18 より繊度を用いて計算し た。試料繊維の断面はほぼ真円である。 SH 繊維お よびST 緘維について求めた抎散係数をそれぞれ $D^{\mathrm{SH}}$ および $D^{\mathrm{ST}}$ を用いて表した。

\section{D. 染料 2 色性}

Congo Red (CR) による 2 色性（以下, CR2 色 性 ${ }^{10)}$ と呼ぶ）を測定した，すなわち，原料調製時に紡 系原液から凝固させたゲルフィラメントを，50\%工 タノール水溶液中で, $\mathrm{CR}$ の溶液濃度 $0.01 \%, 40^{\circ} \mathrm{C}$ において $8 \mathrm{hr}$ 染色した。 CR で染色したゲルフィラ メントを2.1A 項に記載した方法により，熱延伸，無 緊張下で熱風乾燥後 $127^{\circ} \mathrm{C}$ で湿熱処理し, $2.1 \mathrm{~A}$ 項の $\mathrm{SH}$ 繊維に相当する $\mathrm{CR}$ 染色試料を調整した。この $\mathrm{CR}$ 染色試料について, $2.2 \mathrm{~A}$ 項の方法により $150^{\circ} \mathrm{C}$ の熱板温度で所定比率の乾熱二次延伸を行った。こ れら試料の CR2 色性值 $D_{\mathrm{CR}}$ は, ダイクローム偏光 フィル夕付顕微分光光度計 DMSP-III（オリンバス 光学製) により, ジメチルフタレート（屈折率 $n_{\mathrm{D}}{ }^{20}=$
1.514）に含浸した CR 染色試料繊維の側面に波長 $500 \mathrm{~nm}$ の直線偏光ミクロスポットを当てて, それ ぞれ偏光面が織維軸と平行方向および直角方向の吸 光度 $K_{\text {u }}, K_{\perp}$ を測定することにより，(4)式から計算 した。

$$
D_{\mathrm{CR}}=\frac{K_{\text {" }}-K_{\perp}}{K_{\text {" }}+2 K_{\perp}}
$$

\section{E. 音波弾性率}

オリエンテック社製パルス式粘弾性測定器 DDV -5 型を用い, 試料長 $50 \mathrm{~cm}$ で測定した.

\section{F. 熱水中の S-S 特性}

テンシロンUTM-IIIに小さな恒温水槽を取付け, $95^{\circ} \mathrm{C}$ の熱水中で単繊維試料を, 原長 $30 \mathrm{~mm}$, 引張速 度 $30 \mathrm{~mm} / \mathrm{min}$ の条件で伸長したときの S-S 曲線 を記録した。

\section{3. 実験結果}

\section{1 乾燥二次延伸と二次延伸縤維の収縮特性}

前述のように湿熱処理温度を $117^{\circ} \mathrm{C}, 127^{\circ} \mathrm{C}$, $132^{\circ} \mathrm{C}$ と変えた $\mathrm{SH}$ 繊維および US 繊維を乾熱二次 延伸した。 二次延伸条件は, 熱板温度を工業的（卜 ウ牽切機）二次延伸におけるとほぼ同じ温度の $150^{\circ} \mathrm{C}$ とし, 延伸比は $1.10 \sim 1.58$ 倍の範囲で変化さ せた。

これらの二次延伸緘維の ST 収縮率を二次延伸比 $\alpha$ に対してプロットすると図 1 が得られる。 沸騰水 処理による収縮により ST 繊維の二次延伸による長 さの変形が延伸前の值, すなわち, ゼロまで完全に 回復したと仮定すれば，そのときの ST 収縮率は $\{(\alpha-1) / \alpha\} \times 100$ である。このような収縮率の ことを完全回復収縮率と呼ぶことにし，これを図 1 に破線で示した。

図 1 では, ST 収縮率は延伸比が小さいときは延 伸比の増加とともに完全回復収縮率曲線に沿って増 加するが, 延伸比がさらに大きくなると完全回復収 縮率曲線より低い方向へ離れ始める. 完全回復収縮 率曲線から離れ始める延伸比は, US 緘維が最も小 さくて 1.20 末満であり, SH 繊維では熱処理温度が 高いほど，すなわち SH 収縮率が大きいほど大きく なる，さらに延伸比を増していくと，ST 収縮率は 最大值に達し, それ以上の延伸比では低下を示す. $\mathrm{ST}$ 収縮率の最大值も, SH 繊維の熱処理温度が高 い(SH 収縮率が大きい) 試料ほよ゙大きい。これらの 現象は,アクリル繊維の湿潤状態のガラス転移点 


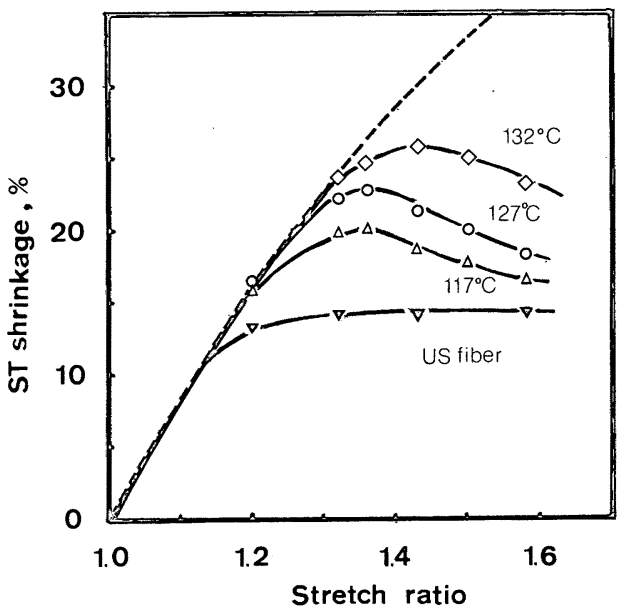

Fig. 1 ST shrinkage in boiling water of ST fiber obtained by the secondary dry heat-stretching at $150^{\circ} \mathrm{C}$. SH fiber was preliminarily steam-heated at different temperatures shown in figure. Dotted line is the calculated shrinkage which gives $100 \%$ recovery.

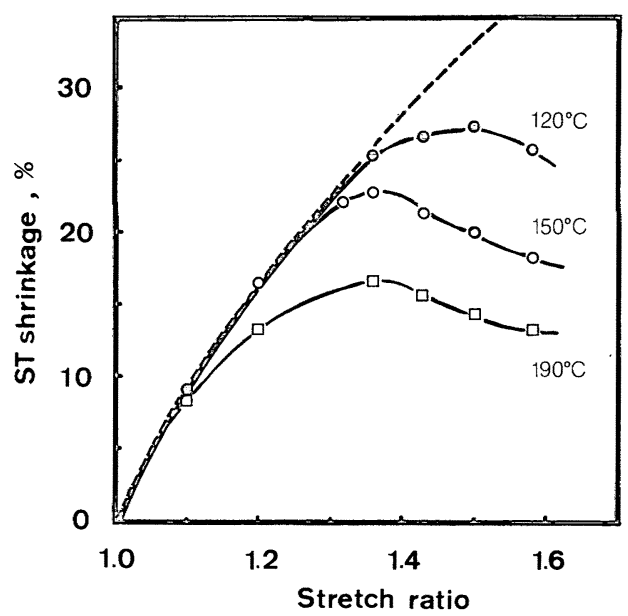

Fig. 2 ST shrinkage in boiling water of ST fiber obtained by the secondary dry heat-stretching at different temperatures shown in figure. SH fiber was preliminarily steamheated at $127^{\circ} \mathrm{C}$. Dotted line is the calculated shrinkage which gives $100 \%$ recovery.

(以下湿ガラス転移点) $70 \sim 80^{\circ} \mathrm{C}^{11 \sim 13)}$ を明らかに越え るST 収縮率測定温度（沸騰水温度）において弾性 回復（すなわちゴム弾性による回復）可能な変形量 に各 SH 繊維ごとの限界值が存在することを示唆す るあのである。図 2 には, 熱処理温度 $127^{\circ} \mathrm{C}$ の $\mathrm{SH}$

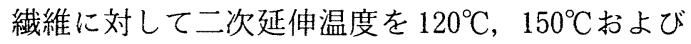

$190^{\circ} \mathrm{C}$ と変化させた場合の ST 収縮率一延伸比の関 係を示した。 二次延伸温度が低い場合の方が ST 収 縮率は大きく，また完全回復収縮率曲線から離れる 延伸比む大きい.このように回復性は延伸温度 $120^{\circ} \mathrm{C}$ 比べて $190^{\circ} \mathrm{C}$ ば著しく低下する.

\section{2 乾熱二次延伸に伴う染色性の変化}

US 繊維および湿熱処理温度 $117^{\circ} \mathrm{Cおよび} 127^{\circ} \mathrm{C}$ の SH 繊維を延伸比 1.58 倍に二次延伸した ST 繊 維について平衡染着量を測定して表 1 に示した。延 伸温度は前述の $150^{\circ} \mathrm{C}$ 以外に一部 $190^{\circ} \mathrm{C}$ 加えた （表 1). 延伸前の各繊維に対するカチオン染料 BR18 による平衡染着所要時間 (および染色温度) は, 上の順に $1 \mathrm{hr}\left(110^{\circ} \mathrm{C}\right), 7 \mathrm{hr}\left(100^{\circ} \mathrm{C}\right)$ および $7 \mathrm{hr}$ $\left(100^{\circ} \mathrm{C}\right)$ であった。 また延伸比 1.58 倍の ST 繊維の 平衡染着所要時間も上と同様であった，表 1 におい て延伸前の $\mathrm{SH}$ 繊維の平衡染着量は湿熱処理温度が 高い $127^{\circ} \mathrm{C}$ 試料の方が小さい.これは既報の結果 ${ }^{1}$ と 同じである. 次に二次延伸後の平衡染着量は, 延伸 前とほとんよ゙変化していないことが示された。すな わち, 染着座席としてアクセシブルな強酸性基量は 乾熱二次延伸により変化しないことが確かめられ た. 従って乾熱二次延伸による拡散係数 $D$ の変化に 対してアクセシブルな強酸性基量の関与は考慮しな くてもよい. なお，表 1 における平衡染着量の平均 値は $26.0 \mathrm{mg} / \mathrm{g}$ fiberであり，これを染着座席量に 換算すると $61 \mathrm{mmol} / \mathrm{kg}$ fiber となり，この值は原 試料の值 $50 \pm 1 \mathrm{mmol} / \mathrm{kg}$ fiberに比べて $22 \%$ 大き い值である.この結果は, 種々の処理にもかかわら ず平衡染着量が変化しない（表 1) ところから, 繊維 の有する強酸性基はすべて染料に対してアクセシブ ルであると解釈できるから, 結局, 精製したにもか かわらず用いた BR-18 染料の純度が $82 \mathrm{wt} \%$ であ ったとして合理的に説明することができる. またこ の純度の結果は以下に述べる染料拡散係数 $D$ を用 いた議論の論旨には本質的に影響しないと考えてよ W.

次に,一例として, $127^{\circ} \mathrm{C}$ 湿熱処理の $\mathrm{SH}$ 繊維を 1.10〜1.58 倍に二次延伸した試料について, BR-18 染料による $90^{\circ} \mathrm{C}$ での染色速度曲線 $C_{\mathrm{t}} / C_{\infty} \mathrm{VS} . \sqrt{t} フ^{\circ}$ ロ ットを図 3 に示した. さらに湿熱処理温度が $117^{\circ} \mathrm{C}$, $127^{\circ} \mathrm{C}$ おび $132^{\circ} \mathrm{C}$ の $\mathrm{SH}$ 繊維を用いた ST 繊維の $D$ と延伸比との関係を図 4 に示した。 図 4 に参考に 用いたUS 繊維では二次延伸前からすでに $D$ 值は 小さく, 二次延伸比を増しても $D$ 值はあまり変化せ 
Table 1 Equilibrium exhaustion of BR-18 in SH, ST and US fibers.

\begin{tabular}{|c|c|c|c|c|c|}
\hline \multirow{2}{*}{\multicolumn{2}{|c|}{$\begin{array}{l}\text { Steam-heating temperature of SH fiber } \\
\text { Heat-Stretching temperature of ST fiber }\end{array}$}} & $117^{\circ} \mathrm{C}$ & \multicolumn{2}{|c|}{$127^{\circ} \mathrm{C}$} & \multirow{2}{*}{ US fiber } \\
\hline & & $150^{\circ} \mathrm{C}$ & $150^{\circ} \mathrm{C}$ & $190^{\circ} \mathrm{C}$ & \\
\hline \multirow{2}{*}{$\begin{array}{c}\text { Dye exhaustion } \\
\text { (mg } / \mathrm{g} \text { fiber) }\end{array}$} & $\mathrm{SH}$ fiber & 26.5 & & & \multirow{2}{*}{ 26. 8} \\
\hline & ST fiber & 26.5 & 25.4 & 25.5 & \\
\hline
\end{tabular}

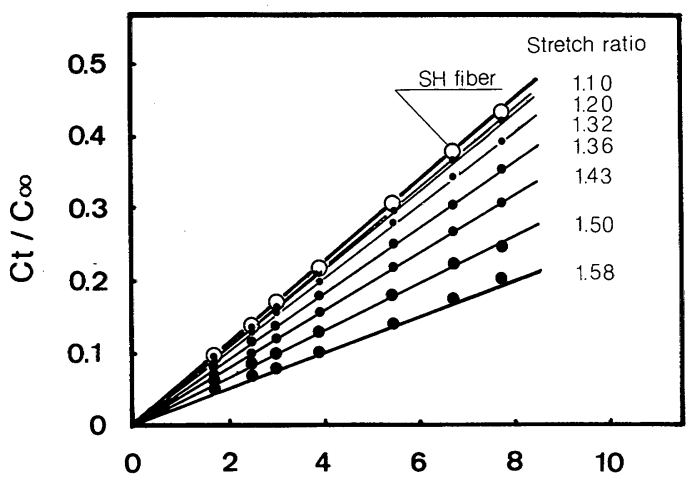

Root dyeing time $\sqrt{t}, \min ^{1 / 2}$

Fig. 3 Example of dyeing rate curves of the ST fiber obtained at $150^{\circ} \mathrm{C}$ with various stretch ratios shown in figure. $\mathrm{SH}$ fiber was preliminarily steam-heated at $127^{\circ} \mathrm{C}$.

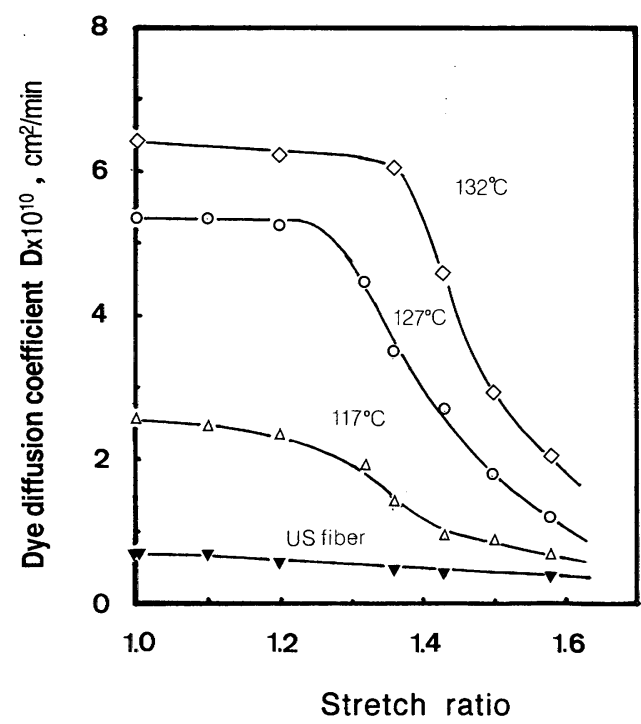

Fig. 4 Relation between dye diffusion coefficient $D$ and stretch ratio of ST fiber obtained by the secondary dry heat - stretching at $150^{\circ} \mathrm{C}$. SH fiber was preliminarily steamheated at different temperatures shown in figure.
ず，わずかに減少する．ST 繊維の場合は低延伸比 では延伸比 1.0 の未延伸 $\mathrm{SH}$ 繊維の $D$ 值とほとんど 変わらないが, 延伸比がある値に達すると $D$ 值は低 下を始め, さらに延伸比が大きくなると $D$ 值は急減 を経て US 繊維の $D$ 值に漸近することが分かる.さ らに図 4 において延伸試料の $D$ が低下を始める延 伸比は湿熱温度が高い SH 繊維ほど高延伸比側に移 動している。このことは SH 綫維の湿熱時の SH 収 縮率の大きさに関連しており，各湿熱処理温度での $\mathrm{SH}$ 収縮率の大きさにちょうど相当する長さだけ試 料を伸ばしたと考えた場合の延伸比を越えると延伸 試料の $D$ 值が急激に低下することが分かる。これは 前項 3.1 で述べた ST 収縮率の挙動においても，こ の延伸比を越えた場合，変形をゴム弾性的に回復で きなくなり，回復性が失われることに対応し，上の 延伸比を境にして繊維の微細構造, 特に染料が拡散 する領域の構造に変化が起きていることが示唆され る.

また二次延伸温度を高くした場合，高い二次延伸 比では回復性が失われることが前項 3.1 において示 されたが，同様にBR-18 の拡散係数む著しく低下 することが分かった（図 5)。ここで，二次延伸温度 が $120^{\circ} \mathrm{C}$ の場合，高延伸比 1.3〜 1.4 倍まで延伸前の $\mathrm{SH}$ 繊維の $D$ 值のレベルが維持されること，また延 伸温度が高くなるほよ゙，拡散係数が低下を始める延 伸比は低くなることが示された。延伸温度 $190^{\circ} \mathrm{Cで}$ は延伸比が 1.2 倍を越えると著しい $D$ 值の低下が示 された. 各延伸温度で $D$ 值が顕著な低下を始める延 伸比は図 2 において収縮率が完全回復収縮率曲線を 離れる延伸比にほぼ対応している。

\section{4. 考察}

アクリル繊維の紡系延伸工程で高度に配向が起こ ると，共重合鎖の AN シーケンス (sequence) の長 い部分がニトリル基の高い凝集力によって微結晶の ように凝集して結節点となり，細かい網目構造を形 成し, 続く高温の湿熱処理工程では共重合成分 MA 


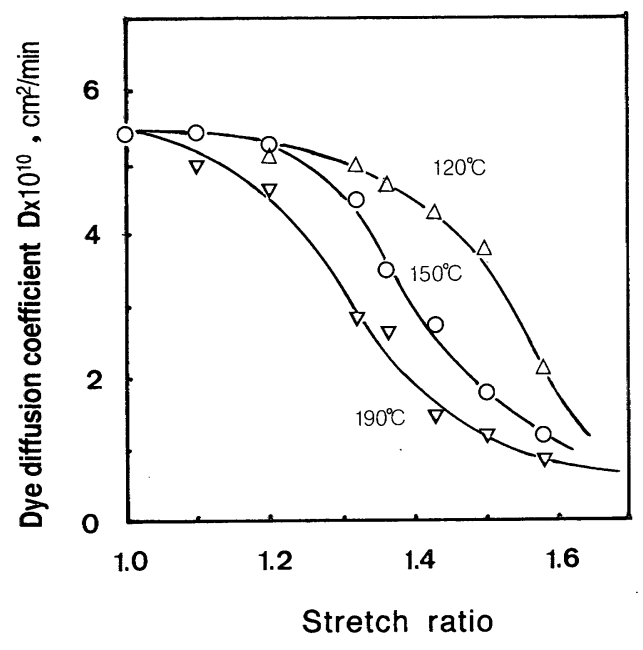

Fig. 5 Relation between dye diffusion coefficient $D$ and stretch ratio of ST fiber obtained by the secondary dry heat-stretching at different temperatures shown in figure. $\mathrm{SH}$ fiber was preliminarily steam-heated at $127^{\circ} \mathrm{C}$.

をより多く含むシーケンスの分子鎖の配向が乱れ， 網目間が拡張し, 無秩序化が促進される一方, 同時 に結晶領域屯再秩序化され, 無定形領域/結晶領域 のいわゆる二相構造化が進行すると考えられてい $ろ^{2,3)}$.

$\mathrm{AN} / \mathrm{MA}$ 重量比 $90 / 10$ 共重合繊維の微細構造に 対する湿熱処理温度の効果を染料の拡散挙動を通し て考えると, 湿熱処理温度が高い SH 繊維は低い $\mathrm{SH}$ 緘維に比べて $\mathrm{BR}-18$ の拡散係数 $D$ が大きく （図 4），また用いた温度範囲でのアレニウスプロッ トの直線部分から求めた拡散の活性化エネルギー $E_{\mathrm{D}}$ は，表 2 に示したように小さい. これらの結果 は, 湿熱処理温度が高くなるほど微結晶とともに染 料の拡散領域である無秩序化領域における分子鎖の 配向が乱れ，無秩序化が進むことと関連していよ う.このような変化は既報 ${ }^{1}$ に述べた繊維の微細構 造の変化のモデルを再現しているが，本報の力点は 次に述べる二次延伸以降にあるので，ここではこれ 以上深くは立ち入らない.

$\mathrm{SH}$ 繊維の二次延伸では, 湿熱処理によって無秩
序化された部分が最初に変形して，ゴム弾性的な性 質を示すと考えられる. ゴム弾性理論は本来網目構 造をもった高分子の非晶構造のガラス転移点以上の 状態における変形を分子論的に扱ったものである. ガラス転移点を越えると, 無秩序化された領域の分 子鎖の熱運動性が高まるので，分子鎖は易動性をも ち，ゴム弾性力に支配される条件になり，変形に対 する復元力が生じる. 一方, 繊維内部で形成された 結晶部分は分子鎖の易動性を妨げ，変形に対する抵 抗として働くから，ゴム弾性にとっての要件である 網目構造の結節点を形成すると考える。ここで，乾 熱二次延伸が行われた $120^{\circ} \mathrm{C}$ 以上の温度, ST 収縮 率測定および染色速度测定の行われたそれぞれ $100^{\circ} \mathrm{Cおよび} 90^{\circ} \mathrm{C}$ 湿熱温度はそれぞれ乾燥状態の ガラス転移点 (以下乾ガラス転移点) $110^{\circ} \mathrm{C}^{14)}$ および 湿ガラス転移点 $\left(70 \sim 80^{\circ} \mathrm{C}\right)$ を越えていて, 無秩序 化領域の分子鎖の易動性は高まり，変形とその回復 に応じる状態にあると考えられる．湿熱処理温度の 異なる $\mathrm{SH}$ 繊維の $95^{\circ} \mathrm{C}$ 熱水中における応力一ひず み曲線 (S-S 曲線) を図 6 に示した。これらの S-S 曲線から, 高延伸後, 無緊張湿熱処理されたアクリ ル繊維の $95^{\circ} \mathrm{C}$ 熱水中の S-S 曲線をモデル的に示す と図 7 のように表すことができる.図 7 の熱水中の

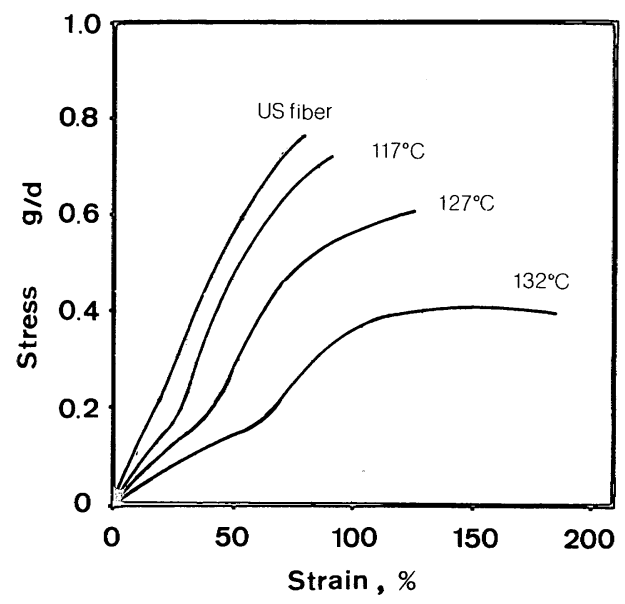

Fig. 6 Stress-strain curves in $95^{\circ} \mathrm{C}$ hot water for . $\mathrm{SH}$ fiber steam-heated at different temperatures shown in figure.

Table 2 Activation energy $E_{\mathrm{D}}$ for the dye diffusion in $\mathrm{SH}$ and US fibers.

\begin{tabular}{lcccc}
\hline \hline Steam-heating temperature $\left({ }^{\circ} \mathrm{C}\right)$ & 117 & 127 & 132 & US fiber \\
\hline$E_{\mathrm{D}}(\mathrm{kcal} / \mathrm{mol})$ & 64 & 50 & 48 & 81 \\
\hline
\end{tabular}


Table 3 Shrinkage in steam-heating and stress-strain properties of SH fiber.

\begin{tabular}{lccc}
\hline \hline Steam-heating temperature $\left({ }^{\circ} \mathrm{C}\right)$ & 117 & 127 & 132 \\
\hline SH shrinkage (\%) & 24.4 & 30.1 & 35.9 \\
SHe shrinkage (\%) & 32.3 & 43.1 & 56.0 \\
\hline REL $(\%)$ & 25 & 40 & 58 \\
$E_{1}(\mathrm{~g} / \mathrm{d})$ & 0.8 & 0.6 & 0.4 \\
$E_{2}(\mathrm{~g} / \mathrm{d})$ & 1.3 & 1.0 & 0.6 \\
\hline
\end{tabular}

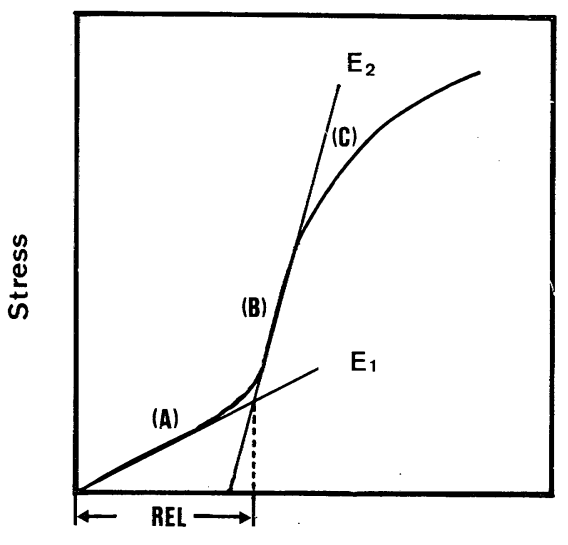

Strain

Fig. 7 A schematic stress-strain curve in $95^{\circ} \mathrm{C}$ hot water for $\mathrm{SH}$ fiber.

S-S 曲線は大別して 3 つの变形領域に分かれる.

(A) 第 1 の領域は低い初期弾性率 $E_{1}$ (1 次ヤング 率）を示す変形部分,（B）次いで初期勾配とは明瞭 に異なる応力の増加部分であり，この曲線に図 7 の ように接線を引いて求めた勾配を 2 次ヤング率 $E_{2}$ と呼ぶことにする. (C) 最後は S-S 曲線が降伏点に 達し, 応力の増加は極めて小さくなって伸び続ける 領域である．図7において， $E_{1}$ は，共重合成分リッ チなシーケンスの部分が湿熱処理によって配向が乱 され，その無秩序化領域)の变形に主として対応す ると考えられる. $E_{1}$ で変形される領域の最大伸長率 を，本報ではゴム状限界伸長率 (Rubbery Elongation Limit, 以下 REL と略称する）と呼ぶことと し，S-S 曲線上で， $E_{1}$ を求めた直線と $E_{2}$ を求めた 直線との交点に対応する伸長率により求めることに する. $E_{2}$ は原試料製造工程での熱延伸により配向し た分子鎖の変形に対応し，この領域では網目の破壊 が起こり, 塑性変形が始まる.この領域の応力が降 伏点に達し, 曲線の勾配がゆるやかになるところ
（図 7 (C) の部分）ふらは流動が起こる（架橋高分子 ではこの流動部分はみられない( $\left.{ }^{15}\right)$. 上述より, $E_{1}$, $E_{2}$ およびREL を求めて表 3 に示す.

ここでREL の大きさと原試料が熱処理（乾熱乾 燥十湿熱処理）によって収縮した長さ $L_{\mathrm{OR}}-L_{\mathrm{SH}}$ と を比較するために $\left(L_{\mathrm{OR}}-L_{\mathrm{SH}}\right)$ を $L_{\mathrm{SH}}$ で除してこれ を $\mathrm{SH}_{\mathrm{E}}(\%)$ と置いて表 3 に示す. 表 3 から REL と $\mathrm{SH}_{\mathrm{E}}$ とは, 熱処理温度の低い $117^{\circ} \mathrm{C}$ の場合には差が

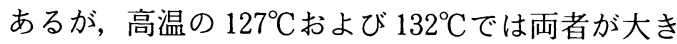
さにおいてほぼ同じになることが分かる。このこと はREL の変形領域を湿熱処理によって配向が乱さ れ無秩序化した領域に対応させる前述の考え方を裏 付けるものである.

さきに（図 1)二次延伸比を大きくすると，延伸に よって受けた ST 繊維の変形が回復しにくくなる結 果をST 収縮率において得た。すなわち，湿熱処理 温度の異なる各 SH 䋐維において，ST 収縮率が完 全回復収縮率曲線から離れることなく完全な回復を 示す上限延伸比を図 1 から読み取ると，それぞれ 1.2 倍. $\left(117^{\circ} \mathrm{C}\right), \quad 1.2 \sim 1.3$ 倍 $\left(127^{\circ} \mathrm{C}\right), \quad 1.3 \sim 1.4$ 倍 $\left(132^{\circ} \mathrm{C}\right)$ であり，また一方，拡散係数の低下しない 上限延伸比は図 4 から $1.1 \sim 1.2$ 倍 $\left(117^{\circ} \mathrm{C}\right), 1.2 \sim 1.3$ 倍 $\left(127^{\circ} \mathrm{C}\right), 1.3 \sim 1.4$ 倍 $\left(132^{\circ} \mathrm{C}\right)$ であった。このよ うに, 収縮率と拡散係数の挙動が変わらない上限延 伸比はほぼ一致する。これらの一致する延伸比を延 伸率\%で表すと，それぞれ $20 \%\left(117^{\circ} \mathrm{C}\right) ， 20 \sim 30 \%$ $\left(127^{\circ} \mathrm{C}\right), 30 \sim 40 \%\left(132^{\circ} \mathrm{C}\right)$ となる.

この延伸率\%までは，各 SH 繊維とも延伸で受け た変形は沸騰水処理によりほぼ完全に回復を示し, $90^{\circ} \mathrm{C}$ 染色においても元の $\mathrm{SH}$ 繊維の拡散係数とほと んど変わらない $D$ 値を示している（図4).

上述に図 7 に示した $\mathrm{S}-\mathrm{S}$ 曲線の特徴に関連させ て以下に考察する。

表 3 に示した REL 值はそれぞれの SH 繊維の湿 熱処理温度の上昇とともに増加する傾向がみられる 
が，上記のように各 SH 繊維において，回復性およ び拡散係数の低下現象の現れる延伸率\%むまたよく 似た増加の傾向を示す.

図 7 の (A) の領域内での二次延伸による変形は, ほぼ完全な収縮回復性を示す延伸比以内にあり，主 に無秩序化された領域が変形されると考えられる. 従って湿ガラス転移点以上の沸騰水温度でゴム弾性 的に完全回復収縮率に近いところまで長さが回復す ると考えられる. さらにこの (A) 領域内の延伸比 において, ST 繊維の拡散係数 $D$ が SH 繊維の $D$ 值 に近い値を維持していることは，染色温度において $\mathrm{ST}$ 繊維が延伸前の SH 繊維の構造にまでゴム弾性 的に復元していることを示唆するものである.US 繊維には, 図 7 (A) の領域は明瞭な形では現れない (図 6).これは高温湿熱処理により形成される無秩 序化領域が存在しないためであると解釈される.

次に図 7 の (B) で示される領域の変形は, 二次延 伸比がさらに大きくなり, ゴム弾性的に回復性のあ る領域（A）の变形を完了することにより起こると 考えられる.この場合は, 湿熱処理により無秩序化 し，配向が乱れて弛緩した分子鎖が延伸により伸び きりながら一部切断が起こり，さらに網目構造の結 節点部分の構造が破壊されるのでゴム弾性による変 形の回復性は延伸とともに失われる.さらに分子鎖 の配向も進むので染料の拡散も阻害される。この変 化は二次延伸温度が高いと促進される。この延伸域 では延伸比を大きくすると，ST 収縮率はかえって 低下し（図 1), 拡散係数 $D$ は急激に低下（図 4) す る.

さらに二次延伸比が大きくなり，図７の（C) の領 域に延伸が移ると，分子鎖間力により形成されて細 かい網目構造の結節点の役割を果たすと考えられる 微結晶構造が破壊され, 分子鎖間のすべりを起こ し，流動を始めて塑性変形が起こると考えられる.

図 4 において, US 繊維の拡散係数 $D$ は SH およ び ST 繊維と比較して明らかに小さく，かつ二次延 伸比を大きくしても $D$ 值の変化はほとんどみられ ない．これは，US 繊維では二次延伸以前に分子鎖 は高度に配向されており ${ }^{21}$ ，二次延伸によって染料 拡散にさらに影響するだけの構造変化が起こらない からである.

次に, 乾熱二次延伸における繊維の配向度の変化 から微細構造を考察することにする.

$\mathrm{SH}$ 繊維 $\left(127^{\circ} \mathrm{C}\right)$ の $150^{\circ} \mathrm{C}$ での乾熱二次延伸にお いて, 2 色性值 $D_{\mathrm{CR}}$ の延伸比に対する関係を図 8

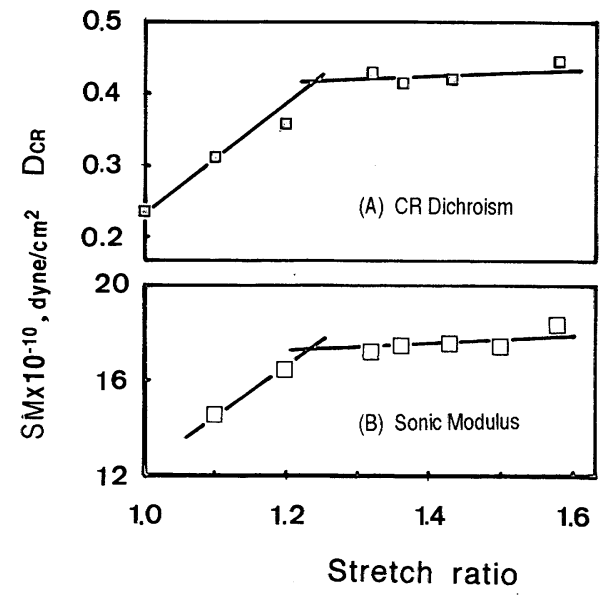

Fig. 8 (A) Dye dichroism $\left(D_{\mathrm{CR}}\right)$ and (B) sonic modulus (SM) vs. stretch ratio for ST fiber obtained by stretching at $150^{\circ} \mathrm{C}$. SH fiber was preliminarily steam-heated at $127^{\circ} \mathrm{C}$.

（A）に示した．図から明らかなように，折れ曲がり 延伸比 1.25 倍までは $D_{\mathrm{CR}}$ は延伸比の増加とともに 増加するが，それ以上の延伸比では $D_{\mathrm{CR}}$ は延伸比を 増しても増加せず, このことは無秩序化領域の分子 鎖の配向が延伸とともにもはや増加しなくなること を意味する．また図 8 （B）には同じく，音波弾性率 （SM）の結果を示すが， $D_{\mathrm{CR}}$ の結果とよく似た結果 が得られている.ここに得られた $D_{\mathrm{CR}}$ と $\mathrm{SM}$ との類 似の対応関係から，SM むまた無称序化領域の分子 鎖の配向度を反映すると考えられ，SM の増加の主 たる原因は無秩序化領域の分子鎖の二次延伸による 配向にあると考えられる，さらに，折れ曲がり延伸 比 1.25 倍以上で $D_{\mathrm{CR}}$ および $\mathrm{SM}$ が増加しなくなる 結果は，延伸比が REL を越えることにより，無秩 序化領域の分子鎖の配向が折れ曲がり延伸比におい て限界に達したことを示すと考えられる。この場 合，さらなる延伸による変形は網目の結節点の働き をしていた微結晶に影響を及ぼすはずであり，さら に分子鎖間に滑りが生じる可能性む十分に考えられ

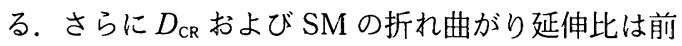
述のST 収縮率の完全回復の上限延伸比および $D$ 值が変化しない上限延伸比とよく対応する。このこ ともまた二次延伸において無秩序化領域の分子鎖の 配向が可能な範囲においてゴム弾性回復むまた可能 であることを示すと考えられる。

次に乾熱二次延伸試料について, ST 収縮率測定 時の沸騰水中収縮後の長さ $L_{\mathrm{SR}}$ と延伸前の長さ $L_{\mathrm{SH}}$ 
（SH 繊維長）との差 $\left(L_{\mathrm{SR}}-L_{\mathrm{SH}}\right)$ を求め, これを $L_{\mathrm{SH}}$ で除して（完全回復に対する）未回復長さ率と呼ぶ ことにする.これはゴム弾性的に長さが回復できな い程度を表す。一方, 乾熱二次延伸前後における拡 散係数の比 $D^{\mathrm{ST}} / D^{\mathrm{SH}}$ を求め, これと末回復長さ率 との関係を図 9 に示した。図から明らかなように, $\mathrm{SH}$ 収縮率，二次延伸倍率，二次延伸温度のいかん にかかわらず両者の関係が同じ曲線上に乗ることが 示された。この結果は，ST 緘維に対する染料拡散 と乾熱二次延伸により収縮回復能を失った微細構造 領域とが強く相関することを示し，このような構造 部分は染料拡散を阻止すると考えられる.

さきに二次延伸温度を高くすると, 二次延伸比の

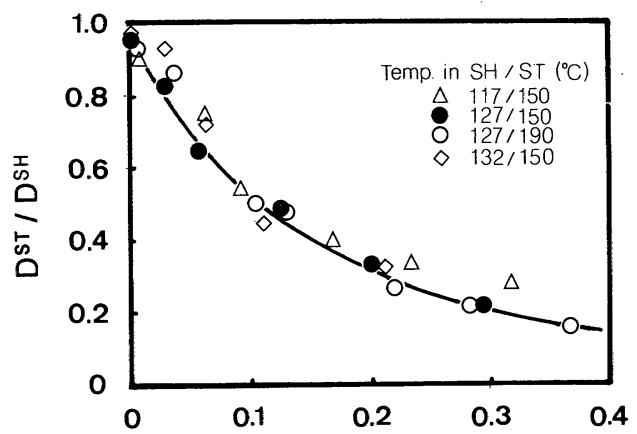

Unrecoverable length ratio $(\mathrm{LSR}-\mathrm{LSH}) / \mathrm{LSH}$

Fig. 9 Relations between the unrecoverable length ratio after relaxed in boiling water and $D_{\mathrm{ST}} / D_{\mathrm{SH}}$ ratio of diffusion coefficient for the ST fiber.
増加に伴うST 収縮率の低下（図 2）および染料拡 散係数の低下 (図 5) が促進されることが示された. 熱板温度を $120^{\circ} \mathrm{C}$ から $190^{\circ} \mathrm{C}$ まで変えて測定した結 果からは，乾ガラス転移点を少し越える $120^{\circ} \mathrm{C} て ゙$ 延 伸すると収縮回復性がよいことが示された（図 2). ガラス転移点以下では延伸張力が大きく，高延伸が 困難になる。一方, $190^{\circ} \mathrm{C}$ 高温では回復性, 染料拡 散性とも著しく低下する．高温延伸では分子鎖が動 きやすくなるので，凝集エネルギーの大きい結節点 領域の分子鎖に变形が及び, SH 繊維の網目構造が 変形し, 新しい結節点の生成が助長されるために構 造変化がゴム状変形にとよ゙まらず，塑性変形にまで 及んだと推察される。

以上において湿式紡糸アクリル繊維を高倍率に熱 延伸後, 無緊張下に熱風乾燥し, $132^{\circ} \mathrm{C}$ までの高温湿 熱処理した繊維を乾熱二次延伸し, 沸騰水中で弛 緩, 収縮させる一連の過程における繊維の微細構造 の変化を論じた。すすおち, アクリル繊維の紡系延 伸工程では分子鎖は高度に配向されて，ニトリル基 の凝集力によって細加い網目構造（分子間凝集エネ ルギー密度の高い部分を網目の結節点とする構造モ デル）を形成して結晶領域と非晶領域との区別が明 確でない構造 (図10の US) をとると考えた。続く高 温の無緊張湿熱処理工程では配向が乱され無秩序化 した分子鎖による非晶領域と，高温による再配列に よって緻密化の進んだ結晶領域とのいわゆる二相構 造が進行すると考えた（図10の SH)，このとき，最 初の “細かい網目”から“大きな網目”一の変化が
SH

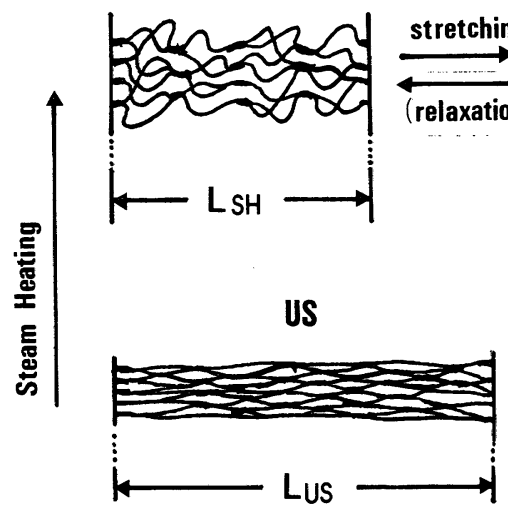

STA

A: stretching within REL
STB

\section{B : stretching over RE}

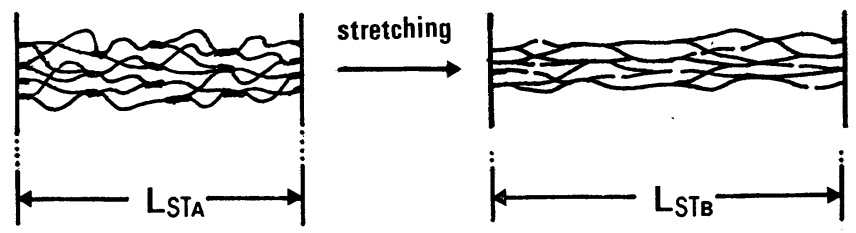

Fig. 10 Model on the structural changes of $\mathrm{SH}$ fiber induced by the secondary dry heatstretching. 
起こっている．湿熱処理温度が高いほど非晶領域の 分子鎖の配向がより乱れ，網目の結節点間の緩和が 大きくなる．結晶領域は網目構造の結節点の役割を 果たしており，再秩序化により緻密化する．次に二 次延伸による変化は図10の SH から ST へ変化で表 される. REL 以内の延伸比では, 湿熱処理によって 無秩序化された領域が変形され，この変形は熱水中 での S-S 曲線モデル（図 7）の領域（A）に対応し, その後に沸騰水中の収縮に伴う熱緩和処理を受ける とき,ゴム弾性的な性質により变形は回復し, 構造 はSH の状態に復元できる（図10の relax を付した 矢印). REL 以内の二次延伸では無秩序化域が変形 され網目間の分子鎖は引き伸ばされるが，網目構造 における結節点の破壊には至らず，変形は回復され る. 湿熱処理温度が高く, $\mathrm{SH}$ 収縮率の大きい場合 は，分子鎖の配向もより大きく乱れていると考えら れる．この場合，REL が大きく， SH 繊維の構造破 壊を伴うことなしに変形可能な延伸倍率もまた大き くなる.

次に，REL を越えて二次延伸を行うと，図10の $\mathrm{ST}_{\mathrm{B}}$ にみられるように，網目間の分子鎖が伸びきっ て切断され, 網目の結節点の働きをしていた結晶構 造部分に変形と破壊が起こる.すなわち図 7 の領域 （B）の変形に対応し, 網目構造が破壊されてゴム弾 性的回復能が失われる.さらに二次延伸比を大きく すると, 図 7 の領域 (C) に相当し, 延伸応力により 分子鎖がすべり続け，ゴム弾性的に回復できない塑 性変形に移ると考えられる.

ここに述べた機構をアクリル繊維のバルキー糸製 造の観点から解釈すると，トウ毫切加工における二 次延伸条件の設定のあり方に示唆が得られる。す す わち, 原料トウのアクリル繊維には, 固有の染色速 度特性扝よび二次延伸繊維の収縮率上限值があり, この染色速度特性を維持しながら固有の収縮率上限 値を効果的に発現させるためには，牽切機による二 次延伸比は熱弾性の限界值 (REL) 以上に高くして はならないことおよび延伸温度はアクリル繊維のガ ラス転移点以上で実質的に延伸が可能となるできる だけ低い温度を選ぶことが望ましい，二次延伸条件 が上記の延伸条件を越えた場合は，原料トウの製造
工程で付与された構造が破壊されて塑性変形を受け るため, 染色性が低下し，本来原料卜ウが固有能力 として有するバルキー系製造に利用できる収縮率が 得られない。このように REL を越える二次延伸は, トウ牽切加工製品の品質变動要因になるので注意を 要する.

\section{5. 結 言}

湿式紡糸アクリル繊維を高倍率に熱延伸した後, 無緊張下で，高温湿熱処理して調製した繊維につい て,さらにガラス転移点以上の温度で乾熱二次延伸 し，延伸に伴う収縮率と染料拡散係数の変化から緎 維の微細構造の变形機構について考察した.

アクリル繊維の二次延伸では，繊維製造段階での 高温湿熱処理により形成された無秩序化領域が，最 初に変形されて，ゴム弾性的な性質を示すと考えら れ，また二次延伸条件がこの無秩序化領域の変形限 界を越えるとゴム弾性的な性質が失われ，収縮率と 染料拡散係数が著しく低下することを明らかにし た.

\section{参考文献}

1）甫天正靖; 䋞学誌，27，144（1971）

2）松村康夫，関口英人，筒井延宏，早原玩朗; 高化，23，289 (1966)

3) B. V. Falkai ; "The 2nd International Conference on Man-made Fibers", Beijing, China (1987)

4) 繊研新聞, 9 月 28 日付 (1989)

5）堀川明; “合綫の紡績・製織技術”，第正編第 1 章「夕ー ボ・ステープラーの基礎」，㵶維機械学会編（1964）

6）高井英雄 ; 繊維誌， 18，257（1965）

7) 高岡 昭;繊維工学，20，778（1967）

8）甫天正靖, 伊藤泰輔; 織学誌,「投稿中」

9) “Colour Index, 3 rd Edition, Vol. 4", p 4015, SDC / AATCC, London/New York (1971)

10）筒井延宏，早原环朗，松村康夫，関口英人; 高化，23，193 (1966)

11) S. Rosenbaum ; J. Appl. Polym. Sci., 7, 1226 (1963)

12） T. H. A. ホサイン, 前田弘邦, 飯島俊郎, 森田全三; 工化, 71,872 (1968)

13) T. H. A. Hossain, T. Iijima, Z. Morita, H. Maeda; J. Appl. Polym. Sci., 13, 541 (1969)

14）真鍋征一，上出健二，中山暢三; 綫維工学，27，156，320 (1978)

15）早原玩朗，松村康夫，関口英人，筒井延宏 ; 高化，23，199 (1966) 